\title{
Isolation, characterization and in vitro anti- salmonellal activity of compounds from stem bark extract of Canarium schweinfurthii
}

\author{
Jean Baptiste SOKOUDJOU ${ }^{1,2}$, Olubunmi ATOLANI ${ }^{2,3}$, Guy Sedar Singor NJATENG ${ }^{1}$, Afsar KHAN², \\ Cyrille Ngoufack TAGOUSOP ${ }^{4}$, André Nehemie BITOMBO ${ }^{2,5}$, Norbert KODJIO ${ }^{1}$ and Donatien GATSING ${ }^{*}$ (D)
}

\begin{abstract}
Background: Bacteria belonging to the Salmonella genus are major concern for health, as they are widely reported in many cases of food poisoning. The use of antibiotics remains a main stream control strategy for avian salmonellosis as well as typhoid and paratyphoid fevers in humans. Due to the growing awareness about drug resistance and toxicities, the use of antibiotics is being discouraged in many countries whilst advocating potent benign alternatives such as phyto-based medicine. The objective of this work was to isolate, characterise the bioactive compounds of Canarium schweinfurthii; and evaluate their anti-salmonellal activity.

Methods: The hydro-ethanolic extract of Canarium schweinfurthii was fractionated and tested for their antisalmonellal activity. The most active fractions (i.e. chloroform and ethyl acetate partition fractions) were then explored for their phytochemical constituents. Fractionation on normal phase silica gel column chromatography and size exclusion chromatography on Sephadex LH-20 led to the isolation of four compounds (maniladiol, scopoletin, ethyl gallate and gallic acid) reported for the first time in Canarium schweinfurthii.

Results: Result indicated that scopoletin and gallic acid had greater activity than the crude extracts and partition fractions. Among the isolated compounds, scopoletin showed the highest inhibitory activity with a MIC of $16 \mu \mathrm{g} / \mathrm{ml}$ against Salmonella Typhimurium and Salmonella Enteritidis.

Conclusions: The overall results of this study indicates that the hydro-ethanolic extract as well as some of isolated compounds have interesting anti-salmonellal activities that could be further explored for the development of potent therapy for salmonellosis. Furthermore, the study adds credence to the folkloric applications of the plant.
\end{abstract}

Keywords: Ethnomedicine, Salmonellosis, Canarium schweinfurthii, Natural substances

\footnotetext{
* Correspondence: gatsingd@yahoo.com

${ }^{1}$ Research Unit of Microbiology and Antimicrobial substances, Faculty of Science, University of Dschang, P.O. Box 67, Dschang, Cameroon

Full list of author information is available at the end of the article
}

(c) The Author(s). 2020 Open Access This article is licensed under a Creative Commons Attribution 4.0 International License, which permits use, sharing, adaptation, distribution and reproduction in any medium or format, as long as you give appropriate credit to the original author(s) and the source, provide a link to the Creative Commons licence, and indicate if changes were made. The images or other third party material in this article are included in the article's Creative Commons licence, unless indicated otherwise in a credit line to the material. If material is not included in the article's Creative Commons licence and your intended use is not permitted by statutory regulation or exceeds the permitted use, you will need to obtain permission directly from the copyright holder. To view a copy of this licence, visit http://creativecommons.org/licenses/by/4.0/ The Creative Commons Public Domain Dedication waiver (http://creativecommons.org/publicdomain/zero/1.0/) applies to the data made available in this article, unless otherwise stated in a credit line to the data. 


\section{Background}

Salmonella is a major source of food-borne illness in humans and a major cause of morbidity, mortality and economic loss both in the poultry and human health sectors. The disease caused by bacteria belonging to Salmonella genus is often called salmonellosis. This pathology remains one of the limiting factors in the development of poultry farming especially in developing countries of Asia and Africa [1] because it causes huge direct and indirect losses [2]. The genus Salmonella is very diverse and today it is composed of more than 2500 serotypes, many of which cause enteric diseases in humans and animals. Many serotypes of Salmonella can infect chickens and some serotypes are well adapted although, Salmonella Gallinarum and Salmonella Pullorum cannot be transmitted to human. However, some serotypes can infect both poultry and human and among these serotypes Salmonella Enteritidis and Salmonella Typhimurium are more prevalent in chickens and notable in human disease outbreaks. These serotypes are most commonly implicated in the human Salmonella infections [3, 4]. The poultry is considered one of the main sources of Salmonella human infection usually through poorly cooked foods [5-9] and foodstuffs of avian origin [10]. Salmonella infection represents a considerable burden in both developing and developed countries. Ubiquitous non-typhoidal Salmonella (NTS) which includes Salmonella Enteritidis and Salmonella Typhimurium annually cause more than 93.8 million illnesses and 155, 000 deaths each year [11]. Salmonella Enteritidis and Salmonella Typhimurium, both NTS are the most frequently occurring serotypes from poultry causing infection in human [3]. Similarly, each year worldwide, typhoidal serotypes among which Salmonella Typhi and Salmonella Paratyphi, cause approximately 22 million cases of typhoid and 216,500 deaths [12].

Resistance of Salmonella to commonly used antimicrobial agents is increasing both in the veterinary and public health sectors and has emerged as a global health challenge. Several Salmonella serotypes are multidrug resistant, and there is evidence of the spread of these strains from animals to humans. Antimicrobial resistance in NTS is considered one of the major public health threats related with food-animal production, as well as the poultry production chain and poultry meat, which is an additional concern in the management of salmonellosis [13]. Many authors [14-17] have reported that several strains of Salmonella isolated from chicken have shown resistance to many antibiotics commonly used in human medicine and some of these strains have been found in humans [14]. Moreover, antibiotic residues in poultry products intended for consumption may lead to hypersensitivity or poisoning in consumers. Due to the growing awareness of resistance issues, the use of antibiotics is strongly discouraged in many countries whilst encouraging the use of plants as a better alternative due to their diverse nature of bioactive principles [18-20]. The large majority of salmonellosis in humans is carried by foodstuffs; mainly those of avian origin [10, 20, 21], therefore controlling avian salmonellosis by using plant could significantly reduce the prevalence of human gastroenteritis [20]. Several studies have focused on medicinal plants as new control strategies for human salmonellosis [22, 23] or avian salmonellosis [24-28]. But, to our knowledge, no phytomedicine has yet been formulated to control avian salmonellosis. Canarium schweinfurthii Engl. (Burseraceae), is a tree with a cylindrical bole, native to tropical West Africa and grows to about $50 \mathrm{~m}$ high [29]. This plant is mainly found in equatorial forest regions from Cameroon, Central African Republic, Gabon to Congo [30] and is used in folk medicine for the treatment of various diseases including malaria, diarrhea and Typhoid fever [31, 32]. Previous studies of Sokoudjou et al. [20, 28] showed that the hydroethanolic extracts of Canarium schweinfurthii were active both in vitro and in vivo against several serotypes of Salmonella. The objective of this work was to isolate, characterise the bioactive compounds of Canarium schweinfurthii; and evaluate their anti-salmonellal activity.

\section{Methods}

\section{General experiment}

Reagents which include ammonium cerium sulphate, were of analytical grade. Solvents were distilled before being used (St Louis, MO, USA). Thin Layer Chromatography (TLC) was performed on pre-coated silica gel with thickness $0.20 \mathrm{~mm} 60 \mathrm{~F}_{254}$ plates (MerckKGaA, Germany) and viewed under the UV light (254 and 365 $\mathrm{nm})$. NMR analyses which included ${ }^{1} \mathrm{H}$ NMR, ${ }^{13} \mathrm{C}$ NMR, DEPT 90, DEPT 135, 2D NMR (COSY, HSQC), NOESY and ROESY were performed using deuterated solvents (Acétone- $d_{6}, \mathrm{CD}_{3} \mathrm{OD}$ and/or $\mathrm{CDCl}_{3}$ ) on $400 \mathrm{MHz} \mathrm{NMR}$ (Ascend $^{\mathrm{TM}} 400$, Bruker) with TMS as internal reference. ESI-MS spectra of the compounds were recorded on a Bruker-Ion Trap MS (MicroTOF-Q mass spectrometer, Bruker) using the positive mode.

\section{Plant collection, identification and extraction}

Canarium schweinfurthii stem bark was harvested in West region of Cameroon and identified at the National Herbarium at Yaoundé-Cameroon, where a voucher specimen was deposited under the reference Number 16929/SRF/Cam. The air-dried plant material (3 Kg) was powdered and macerated at room temperature with $12 \mathrm{~L}$ of ethanol-water system $(50 / 50, \mathrm{v} / \mathrm{v})$. After $48 \mathrm{~h}$, the mixture was filtrated using Whatman №1 filter paper. The filtrate was evaporated using a Rotary evaporator (Büchi 
R200) at reduced pressure to afford the crude extract (265 g, 8.8\%).

We needed no permission to collect the sample since Canarium schweinfurthii is not a protected species in Cameroon.

\section{Fractionation and isolation of bioactive compounds of Canarium schweinfurthii}

The profiling of the hydro-ethanolic extract of Canarium schweinfurthii on TLC plates with several solvent systems showed no promising separation. In order to facilitate isolation, $260 \mathrm{~g}$ of extract was dissolved in distilled water $(700 \mathrm{~mL})$ and successively extracted with hexane $(500 \mathrm{~mL} \times 2)$, chloroform $(500 \mathrm{~mL} \times 2)$, ethyl acetate $(500 \mathrm{~mL} \times 2)$ and $n$-butanol $(500 \mathrm{~mL} \times 2)$ yielding respectively $5.56 \mathrm{~g}, 25.97 \mathrm{~g}, 25.92 \mathrm{~g}$ and $90.89 \mathrm{~g}$ of fractions after evaporation to dryness. These partition fractions were explored for their antibacterial activity and only the most active fractions were selected for the isolation of bioactive principles. Figure 1 below shows the protocol for isolating the bioactive principles of Canarium schweinfurthii.

Part of Chloroform fraction (23 g) was subjected to silica gel column chromatography using $n$-hexane-EtOAc $(85: 15 \rightarrow 00: 100)$ and $\mathrm{MeOH}$, gradient elution. 40 subfractions of $100 \mathrm{~mL}$ each were collected and combined on the basis of their TLC profiles to give 5 fractions: A (1-3), B (4-12), C (13-22), D (23-25) and E (25-40). Sub-fraction A ( $4.5 \mathrm{~g})$ was purified on silica gel column chromatography eluted with $n$-hexane-EtOAc $(95: 5 \rightarrow$ 80:20) to give compound $\mathbf{1}(42 \mathrm{mg})$. The purification of sub-fraction D (4 g) on silica gel column chromatography using $n$-hexane-EtOAc $(70: 30 \rightarrow 20: 80)$ afforded compound $2(57 \mathrm{mg})$ which was recrystallized in EtOAc$\mathrm{MeOH}(20: 80)$.

Part of EtOAc fraction (23 g) was also subjected to silica gel column chromatography eluted with a gradient of $n$-hexane-EtOAc $\quad(70: 30 \rightarrow 00: 100)$ and chloroform$\mathrm{MeOH}(92: 5 \rightarrow 75: 25)$ to afford 60 sub-fractions of 20 $\mathrm{mL}$ which were combined to four sub-fractions: $\mathrm{F}(1-4)$, G (5-15) H (16-24), I (25-60) on the basis of their TLC profile. Sub-fraction G (3.5 g) was purified on silica gel column chromatography using $n$-hexane-EtOAc (50: $50 \rightarrow 00: 100)$ to yield compound $3(21 \mathrm{mg})$ while purification of sub-fraction $\mathrm{H}(2.6 \mathrm{~g})$ on sephadex LH-20 column eluted with chloroform-methanol (50:50) afforded compound $4(60 \mathrm{mg})$. The structures of the isolated compounds were elucidated by combining various techniques comprising 1D Nuclear Magnetic Resonance (NMR): ${ }^{1} \mathrm{H}$ NMR, ${ }^{13} \mathrm{C}$-NMR, DEPT 90, DEPT 135 and 2D NMR (COSY, HSQC), NOESY and ROESY as well as Mass Spectrometry analysis (TOF-ESI-MS). The data of the established structures were compared with those existing in literature.

\section{Anti-salmonellal assay \\ Chemicals for anti-salmonellal assay}

Ciprofloxacin (BDH Chemicals, England) and oxytetracyclin (BDH Chemicals, England) were used as reference antibiotics. P-iodonitrotetrazolium chloride (Sigma-Aldrich, Germany) was used as microbial growth indicator.

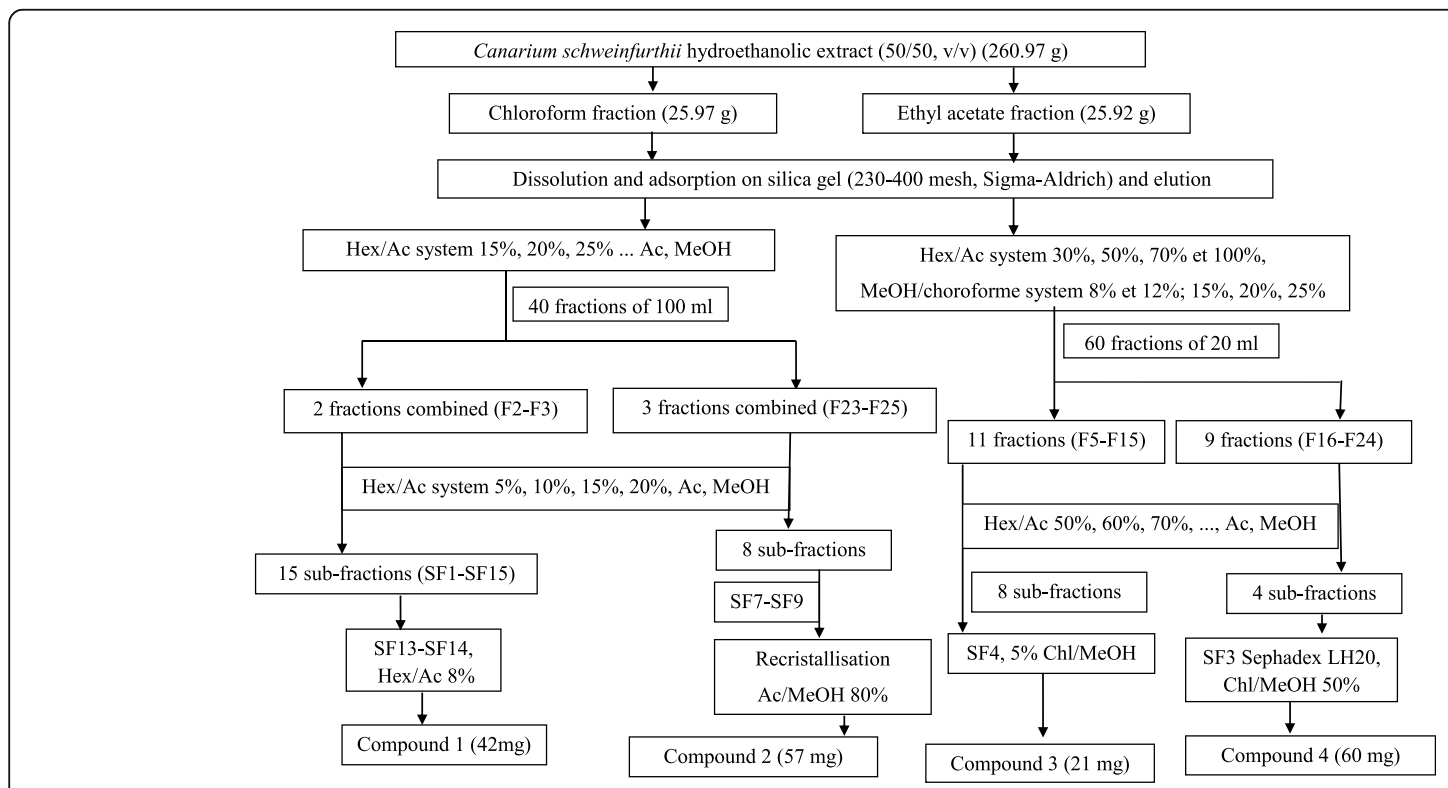

Fig. 1 Flow chart for the isolation of compounds from the hydroethanolic extract of Canarium schweinfurthii 


\section{Test bacteria and culture media}

Three clinical isolates (Salmonella Typhi, Salmonella Enteritidis and Salmonella Typhimurium from Pasteur Center, Yaoundé-Cameroon) and one bacterial strain (Salmonella Typhi ATCC6539 from American Type Culture Collection) were used for antimicrobial evaluation. The culture media used were Salmonella-Shigella Agar (SSA from HiMedia Laboratories, India) and Mueller Hinton Broth (MHB from HiMedia Laboratories, India).

\section{Determination of minimal inhibitory concentrations (MICs) and minimal bactericidal concentrations (MBCs)}

The MIC values of the fractions obtained from partition and compounds from Canarium schweinfurthii were determined in 96-wells microplates using rapid INT colorimetric assay [33, 34]. Briefly, each sample was dissolved in 5\% Dimethyl-sulfoxide (DMSO)/ MHB. The obtained solution was then added to $100 \mu \mathrm{L}$ of $\mathrm{MHB}$, and followed by two-fold serial dilution. Then $100 \mu \mathrm{L}$ of inoculum $\left(1.5 \times 10^{6} \mathrm{CFU} / \mathrm{mL}\right)$ prepared in MHB were added to each well except the negative control wells. The plates were covered with a sterile plate sealer and incubated at $37^{\circ} \mathrm{C}$ for $18 \mathrm{~h}$. The wells containing either MHB or MHB and $100 \mu \mathrm{L}$ of inoculum served as control. After the incubation, $40 \mu \mathrm{L}$ of INT $(0.2 \mathrm{mg} / \mathrm{mL})$ was added to each well and plates were re-incubated at $37^{\circ} \mathrm{C}$ for $30 \mathrm{~min}$, and the MIC of each sample was recorded. MIC was defined as the lowest concentration of the sample that prevented change in colour and exhibited complete inhibition of microbial growth. The MBC was determined by adding $50 \mu \mathrm{L}$ aliquots of the preparations, which did not show any growth after incubation during MIC assays, to $150 \mu \mathrm{L}$ of MHB. These preparations were then incubated at $37^{\circ} \mathrm{C}$ for $48 \mathrm{~h}$. The $\mathrm{MBC}$ was recorded as the lowest concentration of test sample which did not produce a colour change after addition of INT as previously described. The tests were performed in triplicates.

\section{Results}

The yield and physical appearance of each partition fraction of Canarium schweinfurthii extract are as shown below (Table 1).

\section{Characterization of isolated compounds}

The four compounds isolated and characterized from the stem bark extract of Canarium schweinfurthii are as depicted in Fig. 2.

Compound 1: Maniladiol (42 mg) white solid, soluble in methanol, with molecular weight 442 calculated for $\mathrm{C}_{30} \mathrm{H}_{50} \mathrm{O}_{2}$ (ESI-MS: $\mathrm{m} / \mathrm{z} 465.1[\mathrm{M}+\mathrm{Na}]$ ).
Compound 2: Scopoletin (57 mg) yellowish crystals, soluble in acetone, with molecular weight 192 calculated for $\mathrm{C}_{10} \mathrm{H}_{8} \mathrm{O}_{4}$ (ESI-MS: m/z $214.9[\mathrm{M}+\mathrm{Na}]$ ).

Compound 3: Ethyl gallate $(21 \mathrm{mg})$ white solid, soluble in methanol, with molecular weight 198 calculated for $\mathrm{C}_{9} \mathrm{H}_{10} \mathrm{O}_{5}$ (ESI-MS: m/z $221.0[\mathrm{M}+\mathrm{Na}]$ ).

Compound 4: Gallic acid $(60 \mathrm{mg})$ white solid, soluble in methanol, with molecular weight 170 calculated for $\mathrm{C}_{7} \mathrm{H}_{6} \mathrm{O}_{5}$ (ESI-MS: m/z $193.1[\mathrm{M}+\mathrm{Na}]$ ).

The ${ }^{1} \mathrm{H}-\mathrm{NMR}$ and ${ }^{13} \mathrm{C}$-NMR data of isolated compounds are presented in the Tables 2, 3, 4 and 5 .

Anti-salmonellal activity of partition fractions and isolated compounds from stem barks extract of Canarium schweinfurthii

Table 6 shows the inhibition parameters (MIC, MBC, $\mathrm{MBC} / \mathrm{MIC}$ ratio) of the crude extract, partition fractions and isolated compounds of Canarium schweinfurthii against pathogenic Salmonella. The isolated compounds have variable activity $(16 \leq \mathrm{MIC} \leq 1024 \mu \mathrm{g} / \mathrm{mL})$ on the tested Salmonella serotypes. It appears that the activity of isolated compounds is greater than those of the crude extract and partitions. Among the partition fractions, chloroform and ethyl acetate fractions showed the best anti-salmonellal activity while among the isolated compounds, scopoletin showed the highest inhibitory activity with a MIC of $16 \mu \mathrm{g} / \mathrm{mL}$ against Salmonella Typhimurium and Salmonella Enteritidis. MIC values of other compounds and extract ranged between 128 and $1024 \mu \mathrm{g} / \mathrm{mL}$, while hexane and residual fractions are the less active substances with MICs of 512 or $1024 \mu \mathrm{g} / \mathrm{mL}$.

\section{Discussion}

The antimicrobial effects of some plants and their extracts are well known today $[39,40]$; the diversity of plant species is a valuable source for the search for new classes of antibiotics. These plants may proffer valuable alternative to address certain human and veterinary health challenges. It is in this perspective that the hydro-ethanolic extract of Canarium schweinfurthii has been explored for its antisalmonellal activity and its bioactive compounds. Several plants are traditionally used against human salmonellosis [41-46] and avian salmonellosis [24-26, 47]. Plants with

Table 1 Yield and physical appearance of each partition fraction of Canarium schweinfurthii stem barks extracts

\begin{tabular}{llll}
\hline Partitioned fractions & $\begin{array}{l}\text { Yields } \\
\text { (\%) }\end{array}$ & \multicolumn{2}{l}{ Physical characteristics } \\
\cline { 3 - 4 } & Color & Physical appearance \\
\hline Hexane fraction & 2 & Green & Oily \\
Chloroform fraction & 10 & Dark brown & Oily \\
Ethylacetate fraction & 10 & Brown & Solid \\
n-butanol fraction & 34 & Blackish & Cristalline powder \\
Residual fraction & 38 & Blackish & Sticky semi-solid (Syrup) \\
\hline
\end{tabular}




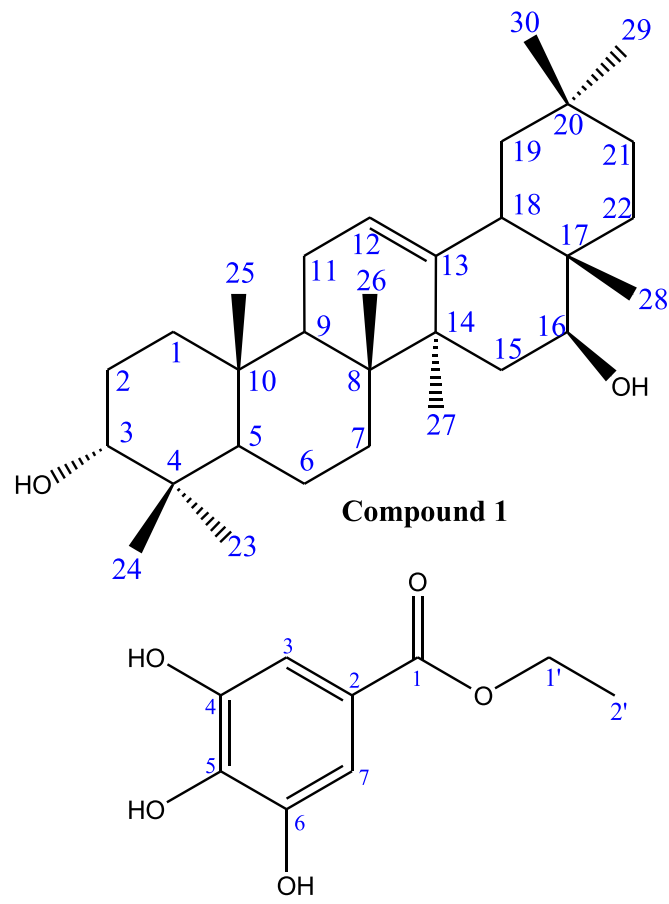

Compound 3<smiles>COc1cc2ccc(=O)oc2cc1O</smiles>

Compound 2

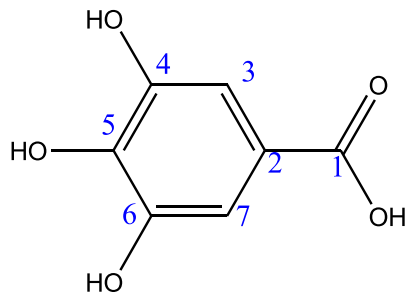

Compound 4

Fig. 2 Chemical structures of isolated compounds from Canarium schweinfurthii stem barks extract

high anti-salmonellal potential that show promise for the control of avian salmonellosis include Aloe secundiflora [47], Thymus vulgaris [48], Curcuma longa and Scutellaria baicalensis [25] and Erica mannii [27]. Plant extracts as well as traditionally improved drugs are one of the promising ways to combat human salmonellosis [23, 47, 49]. Several authors [22, 23, 28, 50-53] have shown that plant extracts depending on their concentrations are active both in vitro and in vivo against several Salmonella serotypes. Most of these extracts treat salmonellosis in the same range of time as conventional medicines. These findings corroborate our results which showed that the hydroethanolic extract of Canarium schweinfurthii is active against Salmonella serotypes with MIC range from 64 to $128 \mu \mathrm{g} /$ $\mathrm{ml}$, moreover this extract have previously demonstrated an in vivo anti-salmonellal activity [20], curing avian salmonellosis on day 9 and with the doses 19 and $75 \mathrm{mg} / \mathrm{kg}$ bw of the extract. In addition to the therapeutic efficacy of the hydroethanolic extract of Canarium schweinfurthii, the antibacterial activity of its partitions was evaluated. Among the partitions, chloroform and ethyl acetate fractions showed the best anti-salmonellal activity. It also appears that the activity of isolated compounds is greater than those of the crude extract and partitions. This could be due to the low concentration of these compounds in the plant extract or to the antagonism effect of other compounds present in the same extract. The anti-salmonellal activity of plants is linked to the diversity and complexity of their secondary metabolites. The in vitro antisalmonellal effect of hydroethanolic extract of Canarium schweinfurthii found in this study and its therapeutic efficacy [20] can be linked to a combined action of its secondary metabolites. Indeed, at the molecular level, compounds such as gallic acid and scopoletin found in plants belonging to Canarium genus [54] could act synergistically and could be partly responsible for the anti-infectious activity of Canarium schweinfurthii. In order to verify this possibility and to have a clear idea on the active principles of this plant, the fractionation of its stem bark extract was performed.

Gallic acid, ethyl gallate, scopoletin and maniladiol were isolated from the Canarium schweinfurthii stem bark extract, these compounds were reported for the first time in this medicinal plant species and belong to the classes of polyphenols, triperpenes and coumarins. From the previous reports [54], only gallic acid and scopoletin have been isolated from other plants belonging to the same genus as Canarium schweinfurthii and these compounds were reported to have antibacterial and antioxidant properties. The isolated compounds have variable activities $(16 \leq \mathrm{MIC} \leq 1024 \mu \mathrm{g} / \mathrm{mL})$ against the tested Salmonella serotypes. Among the pure isolated compounds, scopoletin showed the highest inhibitory activity with a MIC of $16 \mu \mathrm{g} / \mathrm{mL}$ against Salmonella Typhimurium and Salmonella Enteritidis. The activity of most of the isolated compounds was less than those of 
Table $2{ }^{1} \mathrm{H}-\mathrm{NMR}$ and ${ }^{13} \mathrm{C}-\mathrm{NMR}$ of compound 1

\begin{tabular}{|c|c|c|c|c|}
\hline \multicolumn{3}{|c|}{ Compound 1} & \multicolumn{2}{|c|}{ Maniladiol, Quijano et al. [35] } \\
\hline Positions & $\begin{array}{l}\delta \mathrm{c} \\
\left(\mathrm{CD}_{3} \mathrm{OD}+\mathrm{CDCl}_{3}, 100 \mathrm{MHz}\right)\end{array}$ & $\begin{array}{l}\delta_{\mathrm{H}}(\text { mult; } J) \\
\left(\mathrm{CD}_{3} \mathrm{OD}+\mathrm{CDCl}_{3}, 400 \mathrm{MHz}\right)\end{array}$ & $\begin{array}{l}\mathrm{Cc} \\
\left(\mathrm{CD}_{3} \mathrm{Cl}, 125 \mathrm{MHz}\right)\end{array}$ & $\begin{array}{l}\left.\delta_{\mathrm{H}} \text { (mult; } J\right) \\
\left(\mathrm{CD}_{3} \mathrm{Cl}, 500 \mathrm{MHz}\right)\end{array}$ \\
\hline 1 & 32.9 & $\begin{array}{l}1.40(1 \mathrm{H} ; m) \\
1.12(1 \mathrm{H} ; m)\end{array}$ & 38.5 & $\begin{array}{l}1.64(1 \mathrm{H} ; m) \\
0.98(1 \mathrm{H} ; m)\end{array}$ \\
\hline 2 & 24.5 & $\begin{array}{l}1.99(1 \mathrm{H} ; m) \\
1.52(1 \mathrm{H} ; m)\end{array}$ & 27.1 & $\begin{array}{l}1.62(1 \mathrm{H} ; m) \\
1.58(1 \mathrm{H} ; m)\end{array}$ \\
\hline 3 & 75.4 & $3.35(1 \mathrm{H} ; d d ; 11.9 ; 4.8)$ & 78.9 & $3.22(1 \mathrm{H} ; \mathrm{dd} ; 11.5 ; 4.5)$ \\
\hline 4 & 37.1 & - & 38.7 & - \\
\hline 5 & 48.8 & $1.30(1 \mathrm{H} ; m)$ & 55.1 & $0.74(1 \mathrm{H} ; \mathrm{dd} ; 11.5 ; 1.5)$ \\
\hline 6 & 18.0 & $\begin{array}{l}1.45(1 \mathrm{H} ; m) \\
1.44(1 \mathrm{H} ; m)\end{array}$ & 18.3 & $\begin{array}{l}1.58(1 \mathrm{H} ; \mathrm{t} ; 3.6) \\
1.41(1 \mathrm{H} ; \mathrm{dd} ; 15.5 ; 12.0)\end{array}$ \\
\hline 7 & 32.4 & $\begin{array}{l}1.62(1 \mathrm{H} ; m) \\
1.38(1 \mathrm{H} ; m)\end{array}$ & 32.6 & $\begin{array}{l}1.54(1 \mathrm{H} ; \mathrm{t} ; 3.5) \\
1.33(1 \mathrm{H} ; \mathrm{t} ; 3.6)\end{array}$ \\
\hline 8 & 39.9 & - & 39.8 & - \\
\hline 9 & 46.5 & $1.06(1 \mathrm{H} ; m)$ & 46.8 & $1.51(1 \mathrm{H} ; \mathrm{dd} ; 11.0 ; 6.5)$ \\
\hline 10 & 36.6 & - & 37.3 & - \\
\hline 11 & 23.4 & $1.91(2 \mathrm{H} ; m)$ & 23.5 & $\begin{array}{l}1.92(1 \mathrm{H} ; \mathrm{ddd} ; 18.5 ; 11.0 ; 3.5) \\
1.86(1 \mathrm{H} ; \mathrm{ddd} ; 18.5 ; 7.0 ; 4.0)\end{array}$ \\
\hline 12 & 122.3 & $5.26(1 \mathrm{H} ; t ; 3.4)$ & 122.3 & $5.25(1 \mathrm{H} ; t ; 3.5)$ \\
\hline 13 & 143.7 & - & 143.5 & - \\
\hline 14 & 43.5 & - & 43.7 & - \\
\hline 15 & 34.9 & $\begin{array}{l}1.71(1 \mathrm{H} ; m) \\
1.26(1 \mathrm{H} ; m)\end{array}$ & 35.5 & $\begin{array}{l}1.67(1 \mathrm{H} ; \mathrm{d} ; 13.0) \\
1.31(1 \mathrm{H} ; \mathrm{dd} ; 13.0 ; 5.0)\end{array}$ \\
\hline 16 & 65.0 & $4.16(1 \mathrm{H} ; d d ; 11.5 ; 4.9)$ & 66.0 & $4.20(1 \mathrm{H} ; \mathrm{dd} ; 11.5 ; 5.0)$ \\
\hline 17 & 37.0 & - & 36.8 & - \\
\hline 18 & 49.2 & $2.16(1 \mathrm{H} ; d d ; 11.5 ; 4.9)$ & 49.0 & $2.15(1 \mathrm{H} ; \mathrm{dd} ; 14.0 ; 4.5)$ \\
\hline 19 & 46.5 & $\begin{array}{l}1.71(1 \mathrm{H} ; m) \\
1.06(1 \mathrm{H} ; m)\end{array}$ & 46.5 & $\begin{array}{l}1.68(1 \mathrm{H} ; \mathrm{t} ; 14.0) \\
1.06(1 \mathrm{H} ; \mathrm{ddd} ; 13.5 ; 4.5 ; 2.5)\end{array}$ \\
\hline 20 & 30.4 & - & 30.9 & - \\
\hline 21 & 34.0 & $\begin{array}{l}1.41(1 \mathrm{H} ; m) \\
1.13(1 \mathrm{H} ; m)\end{array}$ & 34.1 & $\begin{array}{l}1.36(1 \mathrm{H} ; \mathrm{t} ; 3.7) \\
1.15(1 \mathrm{H} ; t ; 3.6)\end{array}$ \\
\hline 22 & 30.5 & $\begin{array}{l}1.91(1 \mathrm{H} ; m) \\
1.88(1 \mathrm{H} ; m)\end{array}$ & 30.5 & $\begin{array}{l}1.83(1 \mathrm{H} ; \mathrm{t} ; 3.4) \\
1.20(1 \mathrm{H} ; \mathrm{t} ; 3.5)\end{array}$ \\
\hline 23 & 27.8 & $0.95(3 \mathrm{H} ; s)$ & 28.0 & $1.00(3 \mathrm{H} ; s)$ \\
\hline 24 & 21.7 & $0.86(3 \mathrm{H} ; s)$ & 15.6 & $0.79(3 \mathrm{H} ; s)$ \\
\hline 25 & 14.8 & $0.99(3 \mathrm{H} ; s)$ & 15.5 & $0.94(3 \mathrm{H} ; s)$ \\
\hline 26 & 16.24 & $1.03(3 \mathrm{H} ; \mathrm{s})$ & 16.8 & $0.99(3 \mathrm{H} ; s)$ \\
\hline 27 & 26.4 & $1.27(3 \mathrm{H} ; \mathrm{s})$ & 27.1 & $1.22(3 \mathrm{H} ; \mathrm{s})$ \\
\hline 28 & 21.4 & $0.80(3 \mathrm{H} ; s)$ & 21.4 & $0.80(3 \mathrm{H} ; s)$ \\
\hline 29 & 32.6 & $0.90(3 \mathrm{H} ; \mathrm{s})$ & 33.2 & $0.89(3 \mathrm{H} ; \mathrm{s})$ \\
\hline 30 & 23.2 & $0.92(3 \mathrm{H} ; \mathrm{s})$ & 23.9 & $0.90(3 \mathrm{H} ; \mathrm{s})$ \\
\hline
\end{tabular}

oxyphylline B $(10 \mu \mathrm{g} / \mathrm{mL})$ isolated from Zizyphus oxyphylla Edgew against Salmonella Typhi [55] and lespedin $(12.25 \mu \mathrm{g} / \mathrm{ml})$ isolated from Brillanta isialamium against Salmonella Typhi [56]. However the antisalmonellal activity of gallic acid and scopoletin against Salmonella Typhi $(32 \mu \mathrm{g} / \mathrm{mL})$ was better than those of Bafoudiosbulbins $\mathrm{A}$ and Bafoudiosbulbins $\mathrm{B}$ isolated from Dioscorea bulbifera L. var. sativa [57]. These results corroborate the finding of Lunga et al. [44] who showed that the anti-salmonellal activity of isolated compounds from Paullinia pinnata Linn ranged from 0.781 to $100 \mu \mathrm{g} / \mathrm{mL}$. According to the Kuete's classification scale [39], the antibacterial activity of a compound is significant when the $\mathrm{MIC}<10 \mu \mathrm{g} / \mathrm{mL} ;$ moderate when $10<$ 
Table $3{ }^{1} \mathrm{H}-\mathrm{NMR}$ and ${ }^{13} \mathrm{C}-\mathrm{NMR}$ of compound 2

\begin{tabular}{|c|c|c|c|c|}
\hline \multicolumn{3}{|c|}{ Compound 2} & \multicolumn{2}{|c|}{ Scopoletin, Mogana et al. [36] } \\
\hline Positions & $\begin{array}{l}\delta_{\mathrm{C}} \\
\text { (acétone- } d_{6}, 100 \mathrm{MHz} \text { ) }\end{array}$ & $\begin{array}{l}\delta_{\mathrm{H}}(\text { mult; } J) \\
\text { (acétone- } d_{6}, 400 \mathrm{MHz} \text { ) }\end{array}$ & $\begin{array}{l}\delta \mathrm{c} \\
\left(\mathrm{CD}_{3} \mathrm{Cl}, 100 \mathrm{MHz}\right)\end{array}$ & $\begin{array}{l}\left.\delta_{\mathrm{H}} \text { (mult; } J\right) \\
\left(\mathrm{CD}_{3} \mathrm{Cl}, 400 \mathrm{MHz}\right)\end{array}$ \\
\hline 1 & - & - & - & - \\
\hline 2 & 160.4 & - & 161.6 & - \\
\hline 3 & 112.5 & $6.20(1 \mathrm{H} ; d ; 9.5)$ & 111.6 & $6.30(1 \mathrm{H} ; d ; 9.5)$ \\
\hline 4 & 143.6 & $7.86(1 \mathrm{H} ; d ; 9.5)$ & 143.3 & $7.63(1 \mathrm{H} ; d ; 9.5)$ \\
\hline 5 & 102.8 & $6.81(1 \mathrm{H} ; s)$ & 103.2 & $6.87(1 \mathrm{H} ; s)$ \\
\hline 6 & 144.9 & - & 144.6 & - \\
\hline 7 & 150.8 & - & 150.2 & - \\
\hline 8 & 108.9 & $7.20(1 \mathrm{H} ; s)$ & 107.4 & $6.95(1 \mathrm{H} ; \mathrm{s})$ \\
\hline 9 & 150.0 & - & 149.7 & - \\
\hline 10 & 112.1 & - & 113.5 & - \\
\hline $6-\mathrm{OCH}_{3}$ & 55.9 & $3.92(3 \mathrm{H} ; \mathrm{s})$ & 56.4 & $3.98(3 \mathrm{H} ; \mathrm{s})$ \\
\hline $7-\mathrm{OH}$ & - & $8.78(1 \mathrm{H} ; \mathrm{s})$ & - & - \\
\hline
\end{tabular}

MIC $\leq 100 \mu \mathrm{g} / \mathrm{mL}$ and low when MIC> $100 \mu \mathrm{g} / \mathrm{ml}$. With regard to this scale, the anti-salmonellal activities of the isolated compound from Canarium schweinfurthii are moderate $(10<\mathrm{MIC} \leq 100 \mu \mathrm{g} / \mathrm{mL})$. Scopoletin and gallic acid are significantly active against Salmonella Typhi, Salmonella Typhi ATCC6539 and Salmonella Typhimurium. These results corroborate those of Okoli et al. [58] who showed that $3 \beta$-hydroxylolean-12,18-diene isolated from Canarium schweinfurthii was active on Salmonella with a MIC of $12.5 \mu \mathrm{g} / \mathrm{ml}$ against Salmonella Typhi. It has been shown that in addition to its immunomodulatory effect [59], scopoletin reduces the intracellular survival of Salmonella Typhi within U937 human macrophage cell line [60]. Gallic acid has in addition to its in vitro and in vivo antibacterial effect against Salmonella Typhimurium [61, 62], an antioxidant activity. These compounds related properties corroborate the findings of Sokoudjou et al. [20] who reported that the ability of the extract of Canarium schweinfurthii to cure salmonellosis in broilers could be explained by its ability to directly kill Salmonella and/or boost the immune system of the host. The dosage of the compounds isolated from this plant can be used to normalize the extract during the phytomedicine evaluation and preparation.

\section{Conclusion}

Gallic acid, ethyl gallate, scopoletin and maniladiol were isolated from the Canarium schweinfurthii stem bark extract. These compounds were reported for the first time in this plant species. The four isolated compounds showed in vitro anti-salmonellal activity against Salmonella serotypes and particularly scopoletin was the most active and highly selective against both non-typhoidal Salmonella and typhoidal Salmonella with MIC of 16 or $32 \mu \mathrm{g} / \mathrm{mL}$. The anti-salmonellal activity of the compounds isolated from Canarium schweinfurthii justifies the use of this plant in traditional medicine and confirms the anti-salmonellal effect of the hydroethanolic extract thus adding credence to its use in the treatment

Table $4{ }^{1} \mathrm{H}-\mathrm{NMR}$ and ${ }^{13} \mathrm{C}-\mathrm{NMR}$ of compound 3

\begin{tabular}{|c|c|c|c|c|}
\hline \multicolumn{3}{|c|}{ Compound 3} & \multicolumn{2}{|c|}{ Ethyl gallate, Ooshiro et al. [37] } \\
\hline Positions & $\begin{array}{l}\delta \mathrm{c} \\
\left(\mathrm{CD}_{3} \mathrm{OD}, 100 \mathrm{MHz}\right)\end{array}$ & $\begin{array}{l}\delta_{\mathrm{H}}(\text { mult; } J) \\
\left(\mathrm{CD}_{3} \mathrm{OD}, 400 \mathrm{MHz}\right)\end{array}$ & $\begin{array}{l}\delta c \\
\left(C D_{3} \mathrm{OD}, 150 \mathrm{MHz}\right)\end{array}$ & $\begin{array}{l}\left.\delta_{\mathrm{H}} \text { (mult; } J\right) \\
\left(\mathrm{CD}_{3} \mathrm{OD}, 600 \mathrm{MHz}\right)\end{array}$ \\
\hline 1 & 168.8 & - & 168.5 & - \\
\hline 2 & 121.7 & - & 121.7 & - \\
\hline $3 / 7$ & 110.0 & $7.07(2 \mathrm{H} ; \mathrm{s})$ & 110.0 & $7.04(2 \mathrm{H} ; s)$ \\
\hline $4 / 6$ & 146.2 & - & 146.4 & - \\
\hline 5 & 139.6 & - & 139.7 & - \\
\hline $1^{\prime}$ & 61.6 & $4.28(2 \mathrm{H} ; 9 ; 7.1)$ & 61.6 & $4.28(2 \mathrm{H} ; 9 ; 7.3)$ \\
\hline $2^{\prime}$ & 14.7 & $1.35(3 \mathrm{H} ; t ; 7.1)$ & 14.6 & $1.33(3 \mathrm{H} ; t ; 7.3)$ \\
\hline
\end{tabular}


Table $5{ }^{1} \mathrm{H}-\mathrm{NMR}$ and ${ }^{13} \mathrm{C}-\mathrm{NMR}$ of compound 4

\begin{tabular}{|c|c|c|c|c|}
\hline \multicolumn{3}{|c|}{ Compound 4} & \multicolumn{2}{|c|}{ Gallic acid, Chanwitheesuk et al. [38] } \\
\hline Positions & $\begin{array}{l}\delta c \\
\left(C D_{3} \mathrm{OD}, 100 \mathrm{MHz}\right)\end{array}$ & $\begin{array}{l}\left.\delta_{H} \text { (mult; }\right) \\
\left(\mathrm{CD}_{3} \mathrm{OD}, 400 \mathrm{MHz}\right)\end{array}$ & $\begin{array}{l}\delta c \\
\text { (acétone- } d_{6}, 100 \mathrm{MHz} \text { ) }\end{array}$ & $\begin{array}{l}\delta_{\mathrm{H}}(\text { mult; } J) \\
\text { (acétone- } d_{6}, 400 \mathrm{MHz} \text { ) }\end{array}$ \\
\hline 1 & 168.8 & - & 167.3 & - \\
\hline 2 & 120.7 & - & 120.8 & - \\
\hline $3 / 7$ & 108.0 & $7.08(2 \mathrm{H} ; s)$ & 109.1 & $7.15(2 \mathrm{H} ; s)$ \\
\hline $4 / 6$ & 145.0 & - & 144.9 & \\
\hline 5 & 138.1 & - & 137.7 & \\
\hline
\end{tabular}

Table 6 Inhibition parameters (MIC, MBC) of partition fractions and isolated compounds from Canarium schweinfurthii against different test microorganisms

\begin{tabular}{|c|c|c|c|c|c|}
\hline \multirow[t]{2}{*}{ Tested samples } & \multirow{2}{*}{$\begin{array}{l}\text { Studied } \\
\text { parameters } \\
(\mu \mathrm{g} / \mathrm{mL})\end{array}$} & \multicolumn{4}{|c|}{ Strain/isolates } \\
\hline & & ST & STs & STM & $\mathrm{SE}$ \\
\hline \multirow[t]{3}{*}{ HEE 50/50 } & MIC & 256 & 128 & 64 & 128 \\
\hline & $M B C$ & 512 & 512 & 256 & 512 \\
\hline & $\mathrm{MBC} / \mathrm{MIC}$ & 2 & 4 & 4 & 4 \\
\hline \multirow[t]{3}{*}{ Hexane partition } & MIC & 1024 & 1024 & 512 & $>1024$ \\
\hline & MBC & $>1024$ & $>1024$ & $>1024$ & $>1024$ \\
\hline & $\mathrm{MBC} / \mathrm{MIC}$ & - & - & - & - \\
\hline \multirow[t]{3}{*}{ Chloroform partition } & MIC & 512 & 1024 & 256 & 1024 \\
\hline & MBC & 1024 & $>1024$ & $>1024$ & $>1024$ \\
\hline & $\mathrm{MBC} / \mathrm{MIC}$ & 2 & - & - & - \\
\hline \multirow[t]{3}{*}{ Ethyle acetate partition } & MIC & 256 & 256 & 128 & 32 \\
\hline & MBC & $>1024$ & 1024 & $>1024$ & 128 \\
\hline & $\mathrm{MBC} / \mathrm{MIC}$ & - & 4 & - & 4 \\
\hline \multirow[t]{3}{*}{ n-butanol partition } & MIC & $>1024$ & 1024 & 512 & $>1024$ \\
\hline & $M B C$ & $>1024$ & $>1024$ & $>1024$ & $>1024$ \\
\hline & $\mathrm{MBC} / \mathrm{MIC}$ & - & - & - & - \\
\hline \multirow[t]{3}{*}{ Residual partition } & MIC & $>1024$ & $>1024$ & $>1024$ & 1024 \\
\hline & MBC & $>1024$ & 512 & 256 & $>1024$ \\
\hline & $\mathrm{MBC} / \mathrm{MIC}$ & - & - & - & - \\
\hline \multirow{3}{*}{$\begin{array}{l}\text { Compound } 1 \\
\text { Maniladiol }\end{array}$} & MIC & 512 & 512 & 32 & 64 \\
\hline & MBC & $>1024$ & $>1024$ & 128 & 256 \\
\hline & $\mathrm{MBC} / \mathrm{MIC}$ & - & - & 4 & 4 \\
\hline \multirow{3}{*}{$\begin{array}{l}\text { Compound } 2 \\
\text { Scopoletin }\end{array}$} & MIC & 32 & 32 & 16 & 16 \\
\hline & $M B C$ & 64 & 128 & 32 & 64 \\
\hline & $\mathrm{MBC} / \mathrm{MIC}$ & 2 & 4 & 2 & 4 \\
\hline \multirow{3}{*}{$\begin{array}{l}\text { Compound } 3 \\
\text { Ethyl gallate }\end{array}$} & MIC & 128 & 1024 & 64 & 1024 \\
\hline & MBC & $>1024$ & $>1024$ & $>1024$ & $>1024$ \\
\hline & $\mathrm{MBC} / \mathrm{MIC}$ & - & - & - & - \\
\hline \multirow{3}{*}{$\begin{array}{l}\text { Compound } 4 \\
\text { Gallic acid }\end{array}$} & MIC & 32 & 32 & 64 & 128 \\
\hline & $M B C$ & 32 & 32 & 128 & 256 \\
\hline & MBC/MIC & 1 & 1 & 2 & 2 \\
\hline \multirow[t]{3}{*}{ Oxytetracycline } & MIC & 8 & 8 & 4 & 2 \\
\hline & MBC & 32 & 64 & 32 & 16 \\
\hline & $\mathrm{MBC} / \mathrm{MIC}$ & 4 & 8 & 8 & 8 \\
\hline \multirow[t]{3}{*}{ Ciprofloxacine } & MIC & 0,5 & 1 & 4 & 4 \\
\hline & MBC & 2 & 2 & 8 & 8 \\
\hline & $\mathrm{MBC} / \mathrm{MIC}$ & 4 & 2 & 2 & 2 \\
\hline
\end{tabular}

ST Salmonella Typhi, STs Salmonella Typhi ATCC6539, STM Salmonella Typhimurium, SE Salmonella Enteritidis, MIC Minimum inhibitory concentration, MBC Minimum bactericidal concentration. 
of avian salmonellosis. Further studies will be necessary to verify the in vivo activity of these compounds and to elucidate their mechanisms of action.

\section{Supplementary information}

Supplementary information accompanies this paper at https://doi.org/10. 1186/s12906-020-03100-5.

\section{Additional file 1.}

\section{Acknowledgements}

Authors thank the researchers of the Natural Products Chemistry Laboratory of CUI, Abbottabad Campus, Pakistan for their useful suggestions.

\section{Authors' contributions}

All the authors contributed to carry out this study. JBS was the principal investigator, OA and GSSN contributed to evaluate the anti-salmonellal activities. CNT, ANB and NK contributed to the fractionation purification and structural elucidation of isolated compounds. NK revised the manuscript, AK and DG co-supervised the work. All authors read and approved the final manuscript.

\section{Funding}

This research work was supported in part by The Academy of Sciences for the Developing World (TWAS) in collaboration with COMSATS University Islamabad (CUI) under grant FR number 3240299471 (TWAS-CIIT Postgraduate fellowship). The obtained fund was used for compound isolation and characterization.

\section{Availability of data and materials}

They are available as Supporting information.

\section{Ethics approval and consent to participate}

Not applicable in this section.

\section{Consent for publication}

All authors read and approved the final manuscript.

\section{Competing interests}

Authors have declared that no competing interests exist.

\section{Author details}

${ }^{1}$ Research Unit of Microbiology and Antimicrobial substances, Faculty of Science, University of Dschang, P.O. Box 67, Dschang, Cameroon. ${ }^{2}$ Natural Products Chemistry Laboratory, Department of Chemistry, COMSATS University Islamabad, Abbottabad Campus-22060, Islamabad, Pakistan. ${ }^{3}$ Department of Chemistry, Faculty of Physical Sciences, University of Ilorin, P.M.B, Ilorin 1515, Nigeria. ${ }^{4}$ Department of Basic Scientific Studies, University Institute of Technology, University of Ngaoundere, P.O.Box 455, Ngaoundere, Cameroon. ${ }^{5}$ Department of Organic Chemistry, Faculty of Science, University of Yaoundé I, P.O. Box 812, Yaoundé, Cameroon.

Received: 20 December 2019 Accepted: 29 September 2020 Published online: 19 October 2020

\section{References}

1. Rajagopal R, Mini M. Outbreaks of salmonellosis in three different poultry farms of Kerala, India. Asian Pac J Trop Biomed. 2013;3(6):496-500.

2. Awa DN, Achukwi MD. Livestock pathology in the central African region: some epidemiological considerations and control strategies. Anim Health Res Rev. 2010;11:235-44

3. Ali MZ, Sultana S. Avian salmonellosis, Newcastle disease and aspergillosis Tech Rep. 2012;25. https://doi.org/10.13140/RG.2.1.1981.0404.

4. Threlfall EJ, Wain J, Peters T, Lane C, De Pinna E, Little CL, et al. Egg-borne infections of humans with Salmonella: not only an S. Enteritidis problem. Worlds Poult Sci J. 2014:70:15-26.

5. Carli KT, Unal CB, Caner V, Eyigor A. Detection of Salmonellae in chicken feces by a combination of tetrathionate broth enrichment, capillary PCR, and capillary gel electrophoresis. J Clin Microbiol. 2001;39:1871-6.
6. Crilly J, Power EP, Cowman HJ, Cryan B, Buckley JF. Epidemiology of Salmonella infection in the south of Ireland. Ir J OfAgri and Food Resea. 2001;40:215-26.

7. INFOSAN (Réseau international des autorités de sécurité sanitaire des aliments). Lutte contre les salmonelles à la source. Note d'information INFOSAN n 03/2007- Salmonelles. 2007:4.

8. Danan C, Granier S, Bohnert M, Piquet C, Lalande F, Fremy S, et al. Surveillance active de la résistance aux antibiotiques des Salmonella isolées de la filière "poulet de chair » à différentes étapes de la chaine alimentaire (données 2008-2009). Bull Épidémiol Sante Anim Aliment. 2008-2009:44:13-7.

9. Batz MB, Hoffmann S, Morris JG. Ranking the disease burden of 14 pathogens in food sources in the United States using attribution data from outbreak investigations and expert elicitation. J Food Prot. 2012;75:1278-91.

10. Mercado M, Ávila J, Rey M, Montoya M, Gamboa A, Carrascal AK, et al. BrotesporSalmonella spp., Staphylococcus aureus y Listeria monocytogenesasociados al consumo de pollo. Biomédica. 2012:32(3):375-85.

11. Majowicz SE, Musto J, Scallan E, Angulo FJ, Kira M, O'Brien SJ, et al. The global burden of non typhoidal Salmonella gastroenteritis. Clin Infect Dis. 2010;50:882-9.

12. WHO (World Health Organisation). Fièvre typhoïde et utilisation des Vaccins en Asie du Sud-Est et la région de l'ouest du pacifique occidental, 20092013. Relevé Epidémiol Hebd 2014;89(40):429-440.

13. Antunes P, Mourão J, Campos J, Peixe L. Salmonellosis: the role of poultrymeat. Clin Microbiol Infect. 2016;22:110-21.

14. Cardinale E, Perrier JD, Aidara A, Tall F, Coudert C, Gueye IL, et al. Identification d'une nouvelle salmonelle multirésistante dans Une viande de poulet de chair au Sénégal. Revue Élev Méd vét Pays trop. 2000;53(1):5-8.

15. Ngoune TL, Tanedjeu KS, Mbofung CMF. Impact de l'utilisation des antibiotiques Sur la sensibilité des bactéries pathogènes de poules dans la ville de Ngaoundéré. Cameroon J Exp Biol. 2009;5(2):52-61.

16. Chen MH, Hwang WZ, Wang SW, Shih YC, Tsen HY. Pulsed field gel electrophoresis (PFGE) analysis for multidrug resistant SalmonellaentericaserovarSchwarzengrund isolates collected in six years (20002005) from retail chicken meat in Taiwan. Food Microbiol. 2011;28(3):399-405.

17. Lamas A, Fernandez-No IC, Miranda JM, Vazquez B, Cepeda A, Franco CM. Prevalence, molecular characterization and antimicrobial resistance of Salmonella serovars isolated from northwestern Spanish broiler flocks (2011-2015). Poult Sci. 2016;95:2097-105.

18. Bada-Alambedji R, Cardinal E, Biagui $C$, Akakpo AJ. Recherche de résidus de substances à activité antibactérienne dans la chair de poulet consommée dans la région de Dakar (Sénégal). Bull Acad Vet Fr. 2004;157(2):67-70

19. Dahan M, Hanotaux P, Durand F, Liebert F. Encadrement des pratiques commerciales pouvant influencer la prescription des antibiotiques vétérinaires. RAPPORT NRM2013-078P/IGF2013-M-006-02/CGAAER N¹3014, 119. 2013:123.

20. Sokoudjou JB, Fodouop SPC, Djoueudam FG, Kodjio N, Kana JR, Fowa AB, et al. Antisalmonellal and antioxidant potential of hydroethanolic extract of Canarium schweinfurthii Engl. (Burseraceae) in Salmonella enterica serovar Typhimurium-infected chicks. Asian Pac J Trop Biomed. 2019:9(11):474-83.

21. Patrick ME, Adcock PM, Gomez TM, Altekruse SF, Holland BH, Tauxe RV, et al. Salmonella Enteritidis infections, United States, 1985-1999. Emerg Infect Dis. 2004;10:1-7

22. Tala DS, Gatsing D, Fodouop SPC, Fokunang C, Kengni F, Djimeli MN. In vivo anti-salmonella activity of aqueous extract of Euphorbia prostrate Aiton (Euphorbiaceae) and its toxicological evaluation. Asian Pac J Trop Biomed. 2015:5(4):310-8.

23. Kodjio N, Atsafack SS, Njateng GSS, Sokoudjou JB, Kuiate J-R, Gatsing D. Antioxidant effect of aqueous extract of Curcuma longa rhizomes (Zingiberaceae) in the typhoid fever induced in Wistarrats model. J Adv Med Pharm Sci. 2016;7(3):1-13.

24. Ayachi A, Alloui N, Bennoune O, Yakhlef G, DaasAmiour S, Bouzid W, et al. Antibacterial activity of some fruits; berries and medicinal herb extracts against poultry strains of Salmonella. American-Eurasian J Agric Environ Sci. 2009;6(1):12-5

25. Varmuzova K, Matulova ME, Gerzova L, Cejkova D, Gardan-Salmon D, Panhéleux M, et al. Curcuma and Scutellaria plant extracts protect chickens against inflammation and Salmonella Enteritidis infection. Poultry Sci. 2015; 94:2049-58

26. Abiala M, Olayiwola J, Babatunde O, Aiyelaagbe O. Akinyemi. Evaluation of therapeutic potentials of plant extracts against poultry bacteria threatening public health. BMC Complement Altern Med. 2016:16(417):1-8. 
27. Tchoua N. Evaluation des activités antisalmonelles et antioxydantes des extraits de Erica mannii chez le poulet de chair. Thèse de Mater, Université de Dshang. Faculté des sciences, école doctorale des Sciences Fondamentales et Technologiques. 2016;97.

28. Sokoudjou JB, Njateng GSS, Fodouop SPC, Kodjio N, Atsafack SS, Fowa AB, et al. In vitro antisalmonellal and antioxidant activities of Canarium schweinfurthii stem bark extracts. Acad J Med Plants. 2018;6(10):331-41.

29. Kamdem RS, Wafo O, Yousuf S, Ali Z, Adhikari A, Rasheed S, Khan IA. Canarene: a triterpenoid with a unique carbon skeleton from Canarium schweinfurthii. Org Lett. 2011;13:5492-5.

30. Coronel RH. Pili nut Canarium ovatum Engl. Promoting the conservation and use of underutilized and neglected crops, Inst. Plant. Genet. Crop Plant Res. Gaters/International Plant Genet. Resour. Institute, Rome, Italy. 1996;

31. Koudou J, Abena AA, Ngaissona P, Bessiere JM. Chemical composition and pharmacological activity of essential oil of Canarium schweinfurthii. Fitoterapia. 2005;76:700-3.

32. Yousuf S, Kamdem RS, Wafo P, Ngadjui BT, HoongKun F. A cocrystal of 3ahydroxy-tirucalla-8,24-dien-21-oic acid and 33-fluoro-tirucalla-7,24-dien-21oic acid. Acta Cryst. 2011;E67:1015-6.

33. Eloff JN. A sensitive and quick microplate method to determine the minimal inhibitory concentration of plant extracts for bacteria. Planta Med. 1998;64:711-3.

34. Mativandlela SPN, Lall N, Meyer JJM. Antibacterial, antifungal and antitubercular activity of Pelargonium reniforme (CURT) and Pelargonium sidoides (DC) (Geraniaceae) root extracts. S Afr J Bot. 2006;72:232-7.

35. Quijano L, Rios T, Fronczek FR, Fischer NH. The molecular structure of maniladiol from Baccharis salicina. Phytochemistry. 1998;49(7):2065-8.

36. Mogana R, Teng-Jin K, Wiart C. Anti-inflammatory, anticholinesterase, and antioxidant potential of scopoletin isolated from Canarium patentinervium Miq. (Burseraceae Kunth). Evidence-Based Complement. Alt. Med. 2013;2013:1-7.

37. Ooshiro A, Hiradate S, Kawano S, Takushi T, Fujii Y, Natsume M, et al. Identification and activity of ethyl gallate as an antimicrobial compound produced by Geranium carolinianum. Weed Biol Manage. 2009;9:169-72.

38. Chanwitheesuk A, Teerawutgulrag A, Kilburn JD, Rakariyatham N. Antimicrobial gallic acid from Caesalpinia mimosoides Lamk. Food Chem. 2007;100:1044-8.

39. Kuete V. Potential of Cameroonian plants and derived products against microbial infections: a review. Planta Med. 2010;76:1-13.

40. Kuete V, Efferth T. Cameroonian medicinal plants: pharmacology and derived natural products. Frontiers in Pharmacol. 2010;1(123):1-19.

41. Pasha C, Sayeed S, Ali MS, Khan MZ. Antisalmonella activity of selected medicinal plants. Turk J Biol. 2009;33:59-64.

42. Kengni F, Tala DS, Djimeli MN, Fodouop SPC, Kodjio N, Magnifouet HN, et al. In vitro antimicrobial activity of Harungana madagascriensis and Euphorbia prostrate extracts against some pathogenic Salmonella sp. Int J Biol Chem Sci. 2013;7(3):1106-18.

43. Tsobou R, Mapongmetsem PM, Van Damme P. Medicinal plants used against typhoid fever in Bamboutos division, Western Cameroon. Ethnobotany Res Appl. 2013;11:163-74.

44. Lunga PK, Tamokou JDD, Fodouop SPC, Kuiate JR, Tchoumboue J, Gatsing D. Antityphoid and radical scavenging properties of the methanol extracts and compounds from the aerial part of Paullinia pinnata. Springer Plus. 2014;3(302):1-9.

45. Porte SM. Overview of folk medecine used for typhoid in India. Int J Res Ayurveda Pharm. 2014;5(2):219-24.

46. Noghogne LR, Gatsing D, Kodjio N, Sokoudjou JB, Kuiate JR. In vitro antisalmonellal and antioxidant properties of Mangifera indica L. stem bark crude extracts and fractions. Br J Pharm Res. 2015;5(1):29-41.

47. Waihenya RK, Mtambo MMA, Nkwengulila G, Minga UM. Efficacy of crude extract of Aloe secundiflora against Salmonella gallinarum in experimentally infected free-range chickens in Tanzania. J Ethnopharmacol. 2002;79(3):317-23.

48. Khan RU, Naz S, Nikousefat Z, Tufarelli V, Laudadio V. Thymus vulgaris: alternative to abtibiotics in poultry feed. World Poult Sci J. 2012:68:401-8.

49. Atsafack SS, Kodjio N, Njateng GSS. SokoudjouJB, Kuiate J-R, Gatsing D. antiinfectious and in vivo antioxidant activities of albizia gummifera aqueous stem bark extract against salmonella typhi-induced typhoid fever in rats. Int J Pharm. 2016;6(2):20-30

50. Iroha IR, llang DC, Ayogu TE, Oji AE, Ugbo EC. Screening for anti-typhoid activity of some medicinal plants used in traditional medicine in Ebonyi state, Nigeria. Afr J Pharm Pharm. 2010;4(12):860-4.

51. Akinyemi Ol, Dada EO. In vivo antityphoid activities and proximate analysis of ethanolic leaf extracts of Parquetina nigrescens. J Pharm Biol Sci. 2014;9(5):115-2.
52. Gul S, Eraj A, Ashraf Z. Glycyrrhiza glabra and Azadirachta indica against Salmonella Typhi: herbal treatment as an alternative therapy for typhoid fever. iMedPub J (Arch Med). 2015;7(6/4):1-5.

53. Ngoudjou TD, Arfat YM, Njateng GSS, Fokunang C, Nyemb JN, Nighat F, et al. GC/MS analysis, antisalmonellal potential of methanol leaf extracts of Tristemma mauritianum and effects on hematological parameters on Wistar rats infected with Salmonella Typhi. Int J Pharm. 2017;7(2):120-31.

54. Mogana R, Wiart C. Canarium L.: A phytochemical and pharmacological review. J Pharm Res. 2011:4(8):2482-9.

55. Kaleem WA, Nisar M, Qayum M, Zia-UI-Haq M, Adhikari A, Feo VD. New 14membered cyclopeptide alkaloids from Zizyphus oxyphylla Edgew. Int J Mol Sci. 2012:13:11520-9

56. Tamokou JDD, Kuiate JR, Tene M, Nwemequela TJK, Tane P. The antimicrobial activities of extract and compounds isolated from Brillanta isialamium. Iran J Med Sci. 2011;36(1):24-31.

57. Teponno RB, Tapondjou AL, Gatsing D, Djoukeng JD, Abou-Mansour E, Tabacchi R, et al. Bafoudiosbulbins a, and B, two anti-salmonellal clerodane diterpenoids from Dioscorea bulbiferaL. Var sativa. Phytochemistry. 2006; 67(17):1957-63.

58. Okoli BJ, Ndukwe Gl, Ayo RG, Habila JD. Inhibition of the developmental stages of ascaris suum and antimicrobial activity of 33-hydroxylolean-12,18diene isolated from the aerial parts of Canarium schweinfurthii (Engl). American Chem Sci J. 2016;11(3):1-11.

59. Manuele MG, Ferraro G, Arcos MLB, López P, Cremaschi G, Anesini C. Comparative immunomodulatory effect of scopoletin on tumoral and normal lymphocytes, Life Sci. 2006:79:2043-8.

60. Acharya D, Bogati B, Risal P. Scopoletin reduces intracellular survival of Salmonella typhi within U937 human macrophage cell line in vitro. Sky J Microbiol Res. 2013;1(6):47-51.

61. Reyes AWB, Hong TG, Hop HT, Arayan LT, Huy TXN, Min W, et al. The in vitro and in vivo protective effects of tannin derivatives against Salmonella enterica serovar Typhimurium infection. Microb Pathog. 2017;109:86-93.

62. López-Romero JC, Valenzuela-Melendres M, Juneja VK, García-Dávila J, Camou JP, Peña-Ramos A, et al. Effects and interactions of gallic acid, eugenol and temperature on thermal inactivation of Salmonella spp. in ground chicken. Food Res Int. 2018;103:289-94.

\section{Publisher's Note}

Springer Nature remains neutral with regard to jurisdictional claims in published maps and institutional affiliations.

Ready to submit your research? Choose BMC and benefit from:

- fast, convenient online submission

- thorough peer review by experienced researchers in your field

- rapid publication on acceptance

- support for research data, including large and complex data types

- gold Open Access which fosters wider collaboration and increased citations

- maximum visibility for your research: over $100 \mathrm{M}$ website views per year

At $\mathrm{BMC}$, research is always in progress.

Learn more biomedcentral.com/submission 